\title{
Nevrose eller brudd?
}

«Ondt ofte lider den Fiskermand / Som ud maa fare, før Hanen galer. / Al dagen pladske i kolde Vand...» Jarle Holm fra Hitra forteller i Tidsskriftet nr. 20/1935 om en fisker som hadde vært utsatt for en ulykke. Uten røntgenundersøkelse kunne diagnosen lett ha blitt en annen (Tidsskr Nor Lægeforen 1935; 55: 1127).

\section{Få symptomer ved fractura cranii med depresjon}

\author{
Av Jarle Holm, Hitra.
}

Den 20. april d. å. søkte en fisker - 27 år gammel mig på kontoret og fortalte at han den 9. april under et forlis fikk et slag av «kappen» i bakhodet, idet han skulde springe op av motorrummet. Han besvimte ikke og husker tydelig hvordan alt foregikk; men han var ør og svimmel og måtte legge sig ned i livbåten da de rodde bort fra vraket. Han glemte igjen ombord sine kontanter bl. a.

Under roturen måtte han legge sig ned bak i båten og hadde nogen brekninger. Han var dog ikke verre enn at han gikk i land fra båten ved egen hjelp efter ca. $1^{1 / 2}$ time. 2-3 timer efter ulykken fikk han intens hodepine som han søkte mig for. Han fortalte også at han ikke tålte å ligge med bakhodet på hodeputen, da blev den meget verre.

Ved undersøkelsen 20. april fantes: ved perkusjon av kraniet angir han ømhet i høire tindingregion og i bakhodet. Likeså ømhet for kompresjon av kraniet forfra baktil. Intet sikkert påviselig ved palpasjon. Ved oftalmoskopisk undersøkelse sees et par småblødninger i høire øiebunn, og der er en liten blødning i høire trommehule.

Røntgen - doktor Bohne, Trondheim - 23. april: I bakhodet sees en lett dislokasjon av kraniebenet fractura cranii. X-foto vedlegges.

Beklageligvis er den mig tilgjengelige litteratur beskjeden, så overskriften står kun for egen regning. Dog synes det å ha vært enkelte vanskeligheter med diagnosen, hvis da ikke røntgen hadde vist frakturen. Og jeg er tilbøielig til å anta at hans diagnose vilde ha blitt posttraumatisk cefalagi - for da ikke å tale om posttraumatisk nevrose.

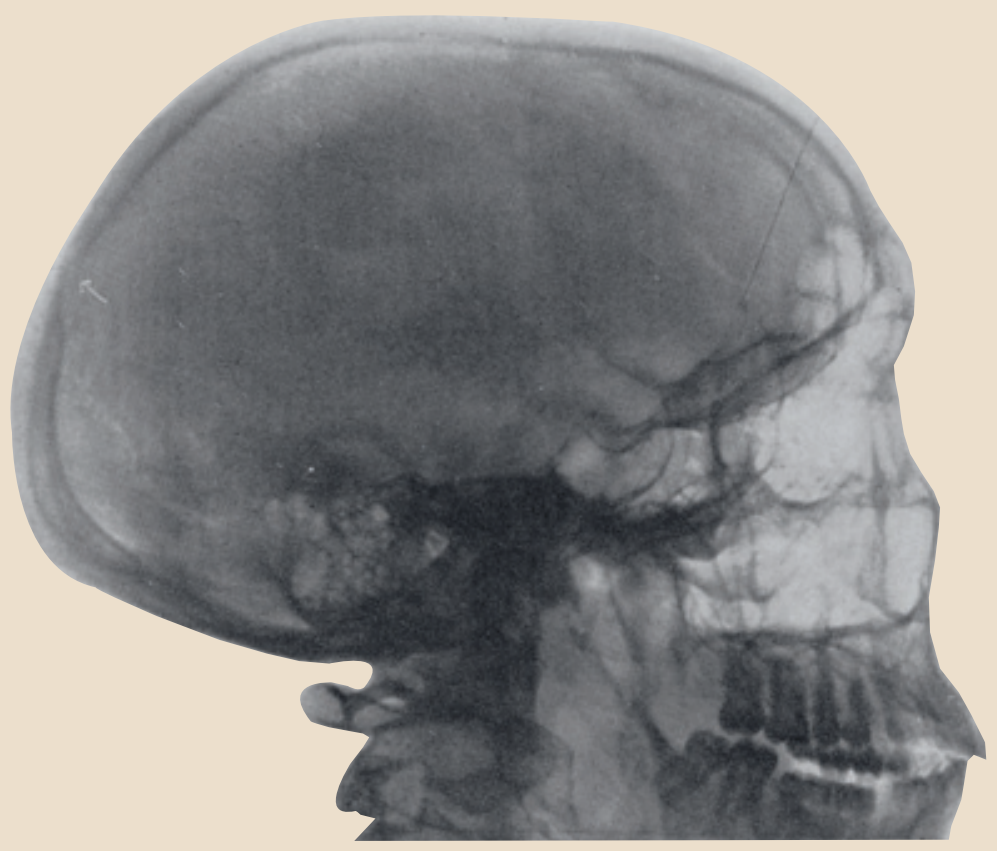

